\title{
TIME AND DIRECTION EFFECT OF BORON (B) AND SILICON (Si) APPLICATION ON OIL PALM (Elaeis guineensis) THROUGH LEAVES
}

\author{
Ageng Kaloko ${ }^{1)}$ \\ ${ }^{1)}$ Faculty of Agriculture, University of Antakusuma J1.Iskandar No.63 Pangakalan Bun Kotawaringin Barat Regency \\ Email: Agengkaloko@gmail.com Telp: 085249606350
}

\begin{abstract}
This study was aimed to obtain the time and the effective way of giving B and Si for reducing the effects of drought. It had been implemented in Bendosari village, Madurejo village, Prambanan sub-district, Sleman regency. The study used $3 \times 3+1$ factorial complete randomized block design (RAKL) with with 3 blocks as replicates. The first factor was the time of fertilization, the second factor was way of fertilization and added one control (control) without fertilization treatment. The data obtained were analyzed using the Varian Analysis (ANOVA) at the 5\% level and continued by the smallest real difference test (LSD) and orthogonal contrast if the variance analysis showed a significant difference between treatments. The results showed that there was no interaction effect between time and direction of B and Si fertilization through leaves on all observed variables of oil palm seedlings exposed to drought stress.
\end{abstract}

Keywords : Boron, Drought, Leaf fertilizer, Oil palm, Roots, Silicon

\section{INTRODUCTION}

Climate change is a natural process that occurs continuously in the long term. Climate change affects all sectors of human life including the agricultural sector. High temperatures and drought are the variables of climate change impacts that are limiting factors in farming activities. The Intergovernmental Panel on Climate Change (IPCC, 2007) reported that the total temperature rise from 1850-1899 to 2001-2005 reaches $0.76{ }^{\circ}$ C. Drought occurs due to water loss through a larger evapotranspiration process which is higher than rainfall or slight rainfall intensity and increasing of el nino periodicity.

According to Jeleel (2009) plants encounters drought stress if the water supply in the root area decreases. This is due to the inadequate availability of water in media and high transpiration rate or a combination of these two factors. Oil palm is susceptible to drought because it has a shallow root system. Lubis (2008) stated that the effective water demand for oil palm is $1,300-1,500 \mathrm{~mm} /$ year and there is no water deficit of up to $250 \mathrm{~mm}$.

Application of Boron (B) and Silicon ( $\mathrm{Si}$ ) can be used as an alternative to reduce the negative impact of drought stress and warming through plant growth. B Application in plants with high temperatures and droughts has a positive effect on cell strength and stability (Putra et al., 2011). In addition B can stimulate the synthesis of several types of antioxidants that play role to eliminate the effects of ROS so it can reduce oxidative damage (Rodriguez et al., 2010). The Si application on drowning plants can improve the efficiency of water use (Gao et al., 2004) and stimulate the synthesis of several antioxidants types (Crusciol et al., 2009). It is further noted that $\mathrm{Si}$ can increase the polysaccharide content of the cell wall so that the cell becomes stronger and less susceptible to damage (Putra et al., 2011) 
due to high temperatures and drought stress. However, there is no information on how to apply the best source of B and Si fertilizers to induce oil palm resistance to high temperature and drought stress. Therefore, research needs to be done on the application of $\mathrm{B}$ and Si source fertilizers to induce oil palm resistance to high temperature stress and drought so that growth and oil palm production remain stable despite exposure to the condition.

\section{MATERIALS AND METHOD}

The research was conducted in Bendosari village, Madurejo village, Prambanan district, Sleman regency, Yogyakarta. The study used 3 x 3 factorial complete randomized block design (RAKL) with 3 blocks as replicates. The first factor was the time of fertilization (A) and the second factor was the way of fertilization (B). Each block had 30 treatment combinations plus one control (control) without $\mathrm{B}$ and $\mathrm{Si}$ fertilization treatment. In this study used boric acid (H3BO3) as B source and sodium silicate $(\mathrm{Na} 2 \mathrm{SiO} 3)$ as $\mathrm{Si}$ source. With each dose of B and Si solution and Si of $0.4 \mathrm{~g} / 1.51 /$ plant. consists of:

The time factor of fertilization

A1 : morning fertilization (08.00)

A2 : afternoon fertilization (12.00)

A3 : evening fertilization (17.00)

Factors of fertilization techniques consists of

B1 : fertilization through the top of leaf surface

B2 : fertilization through the bottom of leaf surface

B3 : Random Fertilization ( the combination between fertilization through top and bottom leaf surfaces)

The oil palm seedlings used in this study were 5 months old (ready to move from pre nursery to main nursery). Then Seedling were grown on polybags with size of $40 \mathrm{~cm}$ x $40 \mathrm{~cm}$. Growing media used was topsoil soil layer (top soil). Seedlings were arranged at $90 \mathrm{~cm} \times 90 \mathrm{~cm} \times 90 \mathrm{~cm}$ spacing with an equilateral triangle pattern.

Testing of oil palm seedling resistance to drought stress was done after the plant maintained for five months under ideal environmental conditions. $\mathrm{B}$ and $\mathrm{Si}$ fertilization were done during the maintenance period.

At the time of drought stress treatment was not be done watering until the plant reached permanent wilt point. To anticipate the possibility of rain fall (during the test), the planting is given a plastic roof. Mathius et al. (2001) stated that oil palm seedlings which are 14 months old with soil cropping medium: sand: Compost (1: 1:1) reaches permanent wilting point after 18 days given drought stress treatment with $10 \%$ moisture content. The study was stopped after the plant reached a permanent wilt point. To investigate the effect of time and the proper application of $\mathrm{B}$ and $\mathrm{Si}$, observations were made on several plant variables including root rigidity, root surface area, total root length, root diameter.

\section{RESULTS AND DISCUSSION}

\section{Results}

The results of variance indicates that there were no interaction effect between the time and direction of $\mathrm{B}$ and $\mathrm{Si}$ fertilization through the leaves on all observed variables of oil palm seedling exposed to drought stress. Therefore, the discussion would be carried out separately between the influence of direction and time of $\mathrm{B}$ and $\mathrm{Si}$ application fertilizer through the leaves on all observed variables.

Table 1 gave the information that there was no significant difference between oil palm seedlings that got $\mathrm{B}$ and $\mathrm{Si}$ applications through leaves with seedlings that did not get $\mathrm{B}$ and $\mathrm{Si}$ applications (control) on root rigidity, root surface area, total root length and root diameter variables after drought stress either when fertilization done in the morning, afternoon or evening. 
Table 1. Influence Of B and Si Fertilization Time Through Leaves to Root Rigidity, Root Surface Area, Total Root Length and Root Diameter Of Oil Palm Seedling.

\begin{tabular}{lrrrr}
\hline \multirow{2}{*}{ Observation Variable } & \multicolumn{4}{c}{ Fertilization Time } \\
\cline { 2 - 5 } & $\begin{array}{c}\text { Morning } \\
(08.00)\end{array}$ & $\begin{array}{c}\text { Afternoon } \\
(12.00)\end{array}$ & $\begin{array}{c}\text { Evening } \\
(17.00)\end{array}$ & \multicolumn{1}{c}{ Control } \\
\hline Root rigidity $(\mathrm{N})$ & $84,67 \mathrm{a}$ & $88,03 \mathrm{a}$ & $88,25 \mathrm{a}$ & $87,27 \mathrm{a}$ \\
Root surface area $\left(\mathrm{cm}^{2}\right)$ & $584,10 \mathrm{a}$ & $761,10 \mathrm{a}$ & $714,00 \mathrm{a}$ & $801,33 \mathrm{a}$ \\
Total root length $(\mathrm{cm})$ & $608,10 \mathrm{a}$ & $839,60 \mathrm{a}$ & $800,50 \mathrm{a}$ & $775,70 \mathrm{a}$ \\
Root diameter $(\mathrm{cm})$ & $0,17 \mathrm{a}$ & $0,15 \mathrm{a}$ & $0,16 \mathrm{a}$ & $0,17 \mathrm{a}$ \\
\hline
\end{tabular}

Information : Different letters behind the numbers on the same line indicate that there was real difference in each treatment, the same followed by the same letter for each observation variable after the dryness was not significantly different from the 5\% LSD level.

Table 2. Influence of B and Si Fertilization Direction Through Leaves to Root Rigidity, Root Surface Area, Total Root Length and Root Diameter of Oil Palm Seedling.

\begin{tabular}{lcccc}
\hline \multirow{2}{*}{ Observation Variable } & \multicolumn{4}{c}{ Fertilization Direction } \\
\cline { 2 - 5 } & Top & Bottom & Top + bottom & Control \\
\hline Root rigidity $(\mathrm{N})$ & $88,52 \mathrm{a}$ & $84,32 \mathrm{a}$ & $88,11 \mathrm{a}$ & $87,27 \mathrm{a}$ \\
Root surface area $\left(\mathrm{cm}^{2}\right)$ & $663,40 \mathrm{a}$ & $721,30 \mathrm{a}$ & $674,40 \mathrm{a}$ & $801,30 \mathrm{a}$ \\
Total root length $\left(\mathrm{cm}^{2}\right)$ & $788,10 \mathrm{a}$ & $727,90 \mathrm{a}$ & $732,20 \mathrm{a}$ & $775,70 \mathrm{a}$ \\
Root diameter $(\mathrm{cm})$ & $0,15 \mathrm{a}$ & $0,16 \mathrm{a}$ & $0,17 \mathrm{a}$ & $0,17 \mathrm{a}$ \\
\hline
\end{tabular}

Information: Different letters behind the numbers on the same line indicate that there is a real difference in each treatment, the letters followed by the same letter for each observation variable after the dryness is not significantly different from the 5\% LSD level.

Table 2 gave information that there was no significant difference between oil palm seedlings that got $\mathrm{B}$ and $\mathrm{Si}$ applications through leaves with seedlings that did not get $\mathrm{B}$ and $\mathrm{Si}$ applications (control) on root rigidity variables, root surface area, total root length and root diameter after drought stress either direction of fertilization done from top, bottom or top + bottom of leaf.

\section{Discussion}

The induction of oil palm seedling resistance to drought stress with $\mathrm{B}$ and $\mathrm{Si}$ application through the leaves simultaneously was not mutually reinforcing between them. Fertilization of $\mathrm{B}$ and $\mathrm{Si}$ through the leaves proved to have no better effect when compared with control. B and Si Application through the leaves in the morning gave less effect than afternoon and evening as well as controls on the root rigidity parameter, root length and root surface area after drought stress.

The control treatment showed the highest value compared to $\mathrm{B}$ and $\mathrm{Si}$ fertilization through leaves on root surface area parameters after drought stress. The highest root rigisity after drought stress was achieved by application of $\mathrm{B}$ and $\mathrm{Si}$ fertilization from the top of the leaf surface and the lowest found in the direction of $B$ and $\mathrm{Si}$ applications from below of the leaf. Application of fertilizer through the leaves during the afternoon and the application direction from the top tends to increase the length of the roots, although not yet seen the difference in fact. Increased root length leads to the ability of plants to absorb water resources from larger soil, so that crop water requirements remain adequate despite exposure to drought stress conditions.

However, the results of this study had not been able to show and explain the 
exact time and direction of $\mathrm{B}$ and $\mathrm{Si}$ applications to induce the resilience of oil palm seedlings.

\section{CONCLUSION}

1. There is no interaction effect between time and direction of $\mathrm{B}$ and $\mathrm{Si}$ fertilization through leaves on all observed variables of oil palm seedlings exposed to drought stress.

2. Not yet able to be explained the right time and direction of $\mathrm{B}$ and $\mathrm{Si}$ application to induce the resilience of oil palm seedlings from drought stress.

3. The results which is fairly positive study in the effort to induce the resilience of oil palm seedlings against drought stress on the polybag scale need to be tested again at the level of the mature oil palm plant in the field to ascertain whether the mature plantation oil palms in the field respond the same as the oil palm seedlings in polybags.

\section{REFERENCE}

Crusciol, C.A.C., Pulz, A.L., Lemos, L.B., Soratto, R.P. and Lima, G.P.P. 2009. Effects of silicon and drought stress on tuber yield and leaf biochemical charecteristics in potato. Crop Physiology and Metabolism 49: 949 - 954.

Gao, X.Q., Ohlander, M., Jeppsson, N., Bjork, L., Trajkovski, V., 2004.Changes in antioxidant effects and their relationshipto phytonutrients in fruits of sea buckthorn (Hippophaerhamnoides L.) during maturation.J. Agric. Food Chem. 48,1485-1490.

Jaleel C.A., Paramasivam M., Abdul W., Muhammad F., HameedJ.A. , Ramamurthy S. and Rajaram P. 2009. Drought Stress in Plants: A Review on MorphologicalCharacteristics and Pigments Composition. International Journal Of Agriculture \& Biology.

Lubis AU. 2008. Kelapa Sawit (Elaeis guineensis Jacq.) di Indonesia Edisi 2. Medan: Pusat Penelitian Kelapa Sawit.

Mathius, N.T., Gede W., Edi G., Hajrial A., Sudirman Y.dan Subronto. 2001. Respons tanaman kelapa sawit (Elaeis guineensis Jacq) terhadap cekaman kekeringan. Menara Perkebunan, 2001, 69 (2), 29-45.

Putra, E.T.S., Zakaria, W., Abdullah, N.A.P and Saleh, G. 2011. Cell development of Musa sp. cv. Rastali fruit in relation to magnesium, boron and silicon availability. Malaysian Journal of Microscopy (In Press).

Rodriguez, M.G.H., Fontes, A.G., Rexach, J., Cristobal, J.J.C., Maldonado, J.M. and Gochicoa, M.T.N. 2010. Role of boron in vascular plants and response mechanisms to boron stresses.Plant Stress 4(2): 115 - 122. 